\title{
The Turner Mountain syenite, Maine, USA: geology, geochemistry, geochronology, petrogenesis, and post-orogenic exhumation
}

\author{
C. WANG ${ }^{1 *}$, A. LUDMAN ${ }^{2}$, AND L. X. WIAO ${ }^{3}$ \\ 1. University of Maine at Presque Isle, Presque Isle, Maine 04769, USA \\ 2. Queens College of the City University of New York, Flushing, New York 11367, USA \\ 3. Chinese University of Geosciences, Wuhan, Hubei 430074, China \\ *Corresponding author <chunzeng.wang@umpi.edu>
}

Date received: 28 April 2014 g Date accepted: 02 September 2014

\begin{abstract}
The Turner Mountain syenite is one of the few plutons located entirely within the Norumbega fault system in the northern Appalachian orogen. It is composed of texturally and mineralogically homogeneous biotite-amphibole syenite and is in faulted contact with mylonitic leucogranite and an unmetamorphosed redbed unit. It is intermediate in $\mathrm{SiO}_{2}$ content (58.7-65.1 wt\%) and ultrapotassic (6.4-7.9 wt\% $\mathrm{K}_{2} \mathrm{O}$ ) with high $\mathrm{K}_{2} \mathrm{O} / \mathrm{Na}_{2} \mathrm{O}$ ratios (2.75-4.15), yet is relatively primitive in terms of $\mathrm{MgO}(2.8-4.9 \mathrm{wt} \%)$, $\mathrm{Ni}$ (average $90.2 \mathrm{ppm}$ ), and Cr (average $210.1 \mathrm{ppm}$ ) contents. It has enriched large-ion-lithophile elements relative to high field strength elements, high contents of light rare-earth elements, and initial ${ }^{87} \mathrm{Sr} /{ }^{86} \mathrm{Sr}$ ratios $(0.7038-0.7068)$ similar to that of OIB basalts. It differs petrologically and geochemically from the neighboring Lucerne-Deblois plutons but is similar to Lincoln syenite located $100 \mathrm{~km}$ to the southwest, also within the Norumbega system. Zircon U-Pb dating using LA-ICP-MS yields a weighted mean age of $410.5 \pm$ 2.4 Ma, slightly younger than the Lincoln syenite $(418 \pm 1 \mathrm{Ma})$. Based on their distinctive geochemical signatures, both were probably products of Late Silurian-Early Devonian ultrapotassic magmatism related to Acadian subduction, generated by partial melting of a mantle wedge metasomatized by potassium-rich fluids during west-directed subduction. This unique magmatism could be attributed to decompressional melting during Late Silurian-Early Devonian slab break-off or delamination. Based on Sr-Nd isotopic compositions, the Turner Mountain syenite magma probably had more crustal interaction than that which formed the Lincoln syenite. The syenite was later exhumed tectonically during brittle reactivation of the Norumbega fault. The reactivation involved regional-scale, high-angle, southeastover-northwest reverse faulting in a transpressional environment and occurred during the Late Devonian and through Mississippian to Permian.
\end{abstract}

\section{RÉSUMÉ}

La syénite du mont Turner est l'un des rares plutons qui se trouvent entièrement dans le système de failles de Norumbega, situé dans la partie nord de l'orogène des Appalaches. Composée de syénite à biotite et à amphibole homogène du point de vue de la texture et de la minéralogie, cette roche est en contact faillé avec le leucogranite mylonitique et une unité de couches rouges non métamorphisée. Elle a une teneur en $\mathrm{SiO}_{2}(58,7-65,1 \%$ en poids) et une composition ultrapotassique $\left(6,4-7,9 \%\right.$ en poids $\left.\mathrm{K}_{2} \mathrm{O}\right)$ intermédiaires et son rapport $\mathrm{K}_{2} \mathrm{O} / \mathrm{Na}_{2} \mathrm{O}$ est élevé $(2,75-4,15)$, mais elle reste tout de même plus ou moins primitive pour ce qui est de la teneur en $\mathrm{MgO}(2,8-4,9 \%$ en poids), Ni (en moyenne 90,2 ppm) et $\mathrm{Cr}$ (en moyenne 210,1 ppm). La syénite possède des éléments lithophiles à grand rayon ionique enrichis comparativement aux éléments à forte liaison atomique, des éléments à haute teneur en terres rares légères et des rapports initiaux de ${ }^{87} \mathrm{Sr} /{ }^{86} \mathrm{Sr}(0,7038-0,7068)$ similaires aux basaltes d'îles océaniques. Elle diffère donc, sur les plans pétrologique et géochimique, des plutons de Lucerne-Deblois voisins, mais s'apparente à la syénite Lincoln qui se trouve à $100 \mathrm{~km}$ au sud-ouest, toujours dans le système Norumbega. Lâge U-Pb sur zircon calculé à l'aide de la LA-ICPMS donne une moyenne d'âge pondérée de 410,5 $\pm 2,4 \mathrm{Ma}$, ce qui est légèrement plus jeune que la syénite Lincoln (418 $\pm 1 \mathrm{Ma}$ ). La signature géochimique particulière des deux éléments indique qu'ils proviennent probablement du magmatisme ultrapotassique de la fin du Silurien-début du Dévonien en lien avec la subduction acadienne, causée par la fusion partielle d'un prisme mantélique métasomatisé par des liquides riches en potassium pendant la subduction vers l’ouest. Ce magmatisme unique peut être attribué à la fusion de décompression pendant la rupture ou la délamination 
des plaques vers la fin du Silurien-début du Dévonien. Selon les compositions isotopiques Sr-Nd, le magma de syénite du mont Turner a probablement eu plus d'interaction crustale que le phénomène à l'origine de la syénite Lincoln. Par la suite, la syénite a été exhumée par voie tectonique pendant la réactivation cassante de la faille de Norumbega. La réactivation, qui était accompagnée de la formation de failles inverses à fort pendage à l'échelle régionale, du sud-est vers le nord-ouest, dans un milieu de transpression, s'est produite à la fin du Dévonien et sest poursuivie du Mississippien au Permien.

[Traduit par la redaction]

\section{INTRODUCTION}

The Norumbega fault system is one of the largest transcurrent, orogen-parallel fault systems in the northern Appalachian orogen (Hubbard et al. 1995; Ludman and West 1999). Initial dextral Norumbega shearing was caused by oblique Acadian plate collision (Swanson 1999) and began at about $380 \mathrm{Ma}$ (Ludman et al. 1999; West 1999; West and Lux, 1993). Early, dominantly ductile strike-slip shearing was followed by several episodes of regional-scale brittle reactivation with dominantly dip-slip motion (Wang and Ludman 2002) that contributed to exhumation from middle crustal depths to the surface and, along some portions of the fault system, appear to have continued to at least the Cretaceous (West and Hubbard 1997; West and RodenTice 2003).

During its lengthy history, Norumbega shearing affected Early Paleozoic metasedimentary rocks folded during the Late Silurian to Devonian Salinic and Acadian orogenies, as well as large granitic plutons that cut those folds, younger unmetamorphosed redbeds, and two unique post-folding ultrapotassic syenites - the Turner Mountain and Lincoln syenite plutons (Fig. 1a). The $418 \mathrm{Ma}$ (Tucker et al. 2001) Lincoln syenite crops out discontinuously over a distance of $75 \mathrm{~km}$ in south-central and mid-coastal Maine and its age (Tucker et al. 2001), chemistry, and petrologic/tectonic relationships have been studied extensively (West et al. 2007).

In contrast, little is known about the Turner Mountain syenite which lies within the Norumbega fault system on Turner Mountain and Little Turner Mountain, $55 \mathrm{~km}$ northeast of Bangor in east-central Maine (Fig. 1a). It has been mentioned by several researchers as an independent body (Stoesser 1966; Gilman 1974; Griffin 1976; Wones 1977, 1980; Wones and Ayuso 1993) but has not been studied in detail prior to our research. Specifically, its contact relationships with adjacent rocks are poorly understood, neither geochronological nor geochemical studies have been completed on the intrusive body, and its relationship to faults of the Norumbega system has not been investigated.

The goals of this research on the Turner Mountain syenite are to reveal its geologic relationship to the neighboring geologic units, determine its crystallization age through $\mathrm{U}-\mathrm{Pb}$ geochronology, interpret its petrogenesis through detailed petrographic and geochemical studies, compare this information with similar data from the Lincoln syenite in south-central Maine, and hence better constrain the timing and temporal extent of early-Acadian ultrapotassic mag- matism in Maine. Additionally, because the Turner Mountain syenite is located within the Norumbega fault system, an additional goal of this research is to document the effects of this fault on the pluton.

\section{REGIONAL GEOLOGIC SETTING}

\section{Stratified Rocks}

The metasedimentary package northwest of the Norumbega fault system in the Turner Mountain area was recently mapped as Flume Ridge Formation of Silurian age (Wang 2014). The formation comprises a typical turbidite suite, composed predominantly of interbedded light grey-, dark grey-, and green-weathering medium to thick beds of feldspathic wacke and siltstone and subordinate, thinly to medium-bedded pelite. A general northeasterly strike at $45^{\circ}-65^{\circ}$ with dips ranging from $45^{\circ}$ to $85^{\circ}$ to both $\mathrm{NW}$ and $\mathrm{SE}$ is prevalent throughout the area. An area mapped as Bucksport Formation of Silurian age extends southwest from the east side of Great Pond and is surrounded by the Lucerne and Deblois plutons (Trefethen 1950; Wing 1957; Osberg et al. 1985), probably as a large roof pendant (Fig. 1a). The Bucksport is similar to the Flume Ridge Formation lithologically and structurally, and also represents a turbidite suite that consists of predominantly dark gray thick feldspathic siltstone and wacke beds and medium-thin layers of pelite. Both the Flume Ridge and Bucksport formations belong to the Fredericton trough. A narrow septum of the Bucksport Formation crops out along the northwestern margin of the Lucerne pluton (Fig. 1a).

A narrow slice of unmetamorphosed redbeds crops out in the Norumbega fault between the Flume Ridge Formation and the Bucksport belt (Fig. 1a) and has recently been named the Great Pond Formation (Wang 2014). The redbeds contain pebble to cobble conglomerate, red sandstone, arkose, siltstone, and mudstone. Clasts include monomineralic quartz, prominent pink potassic feldspar probably derived from the nearby Turner Mountain phenocrysts, grey to white plagioclase feldspars, and a variety of lithic fragments. Some of these fragments are similar to the Flume Ridge or Bucksport formations, but the majority are unmetamorphosed sandstone, some light red, some white, that suggests uplift of early basin sediments and erosion of earlier post-Acadian molasse. Some lithic fragments are granitic and probably derived from the nearby LucerneDeblois plutons due to their textural and mineralogical 


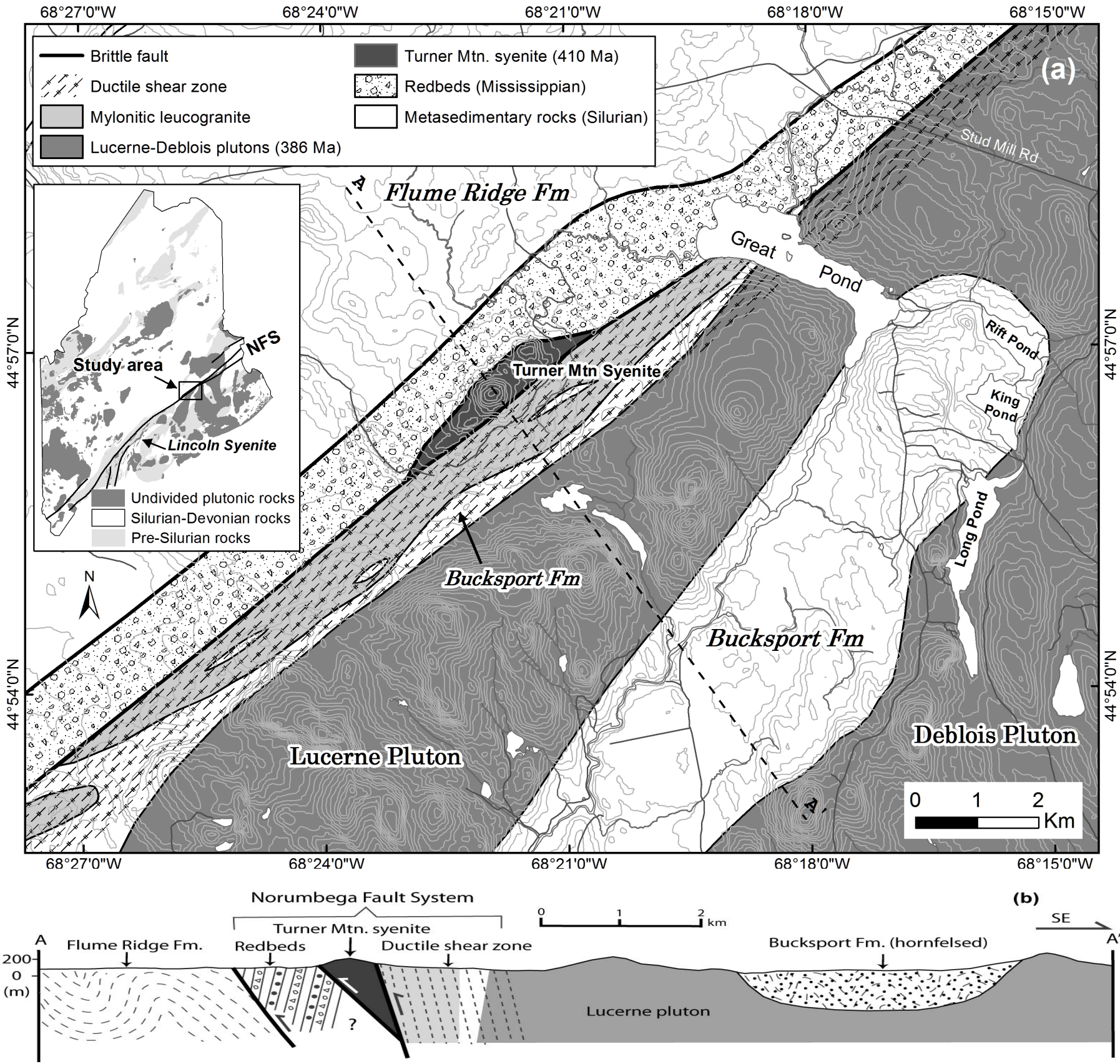

Figure 1. Geologic map (a) and cross-section (b) of the Turner Mountain area.

similarities. Previous studies interpreted the redbeds as post-Acadian molasse sediments deposited in a pull-apart basin produced by brittle reactivation of an original strikeslip fault zone (Wang and Ludman 2002, 2004; Wang 2011). Based on correlation with a similar redbed unit along the length of the Norumbega fault system on the east side of the Maine-New Brunswick border where it is called "Shin Formation (of Mabou Group)" of Early Carboniferous age in New Brunswick (Fyffe 1988), the Great Pond Formation redbeds are assigned a Mississippian age (Wang 2014).

\section{Igneous Rocks}

The Deblois and Lucerne plutons are two large granitic bodies that intruded the pre-Silurian St. Croix, Silurian Fredericton, and Silurian-Devonian Coastal Volcanic belts (Osberg et al. 1985; Ludman et al. 1999; Wang and Ludman 2002). Previous geologic maps show a septum of metasedimentary rocks separating the Deblois and Lucerne plutons northeast of Great Pond (e.g., Osberg et al. 1985), but recent detailed mapping (Wang 2011) revealed scattered outcrops of granite in that area rather than metasedimentary rocks 
and confirmed the connection of the two plutons (Fig. 1a). Observations of both plutons demonstrate that they are similar petrographically; both are very coarse-grained biotite granite, characterized by distinctive pale-white and pink potassic feldspar megacrysts. Both are composed mostly of white-pink perthitic microcline and white sodic plagioclase megacrysts up to $8 \mathrm{~cm}$ long, set with a typical seriate texture in a coarse-grained matrix of subhedral albite and anhedral quartz, biotite, and minor hornblende (Wones 1980). According to Loiselle and Ayuso (1980), Wones (1980), Hogan and Sinha (1989), and Wones and Ayuso (1993), the Lucerne-Deblois plutons are calc-alkaline and chemically metaluminous to mildly peraluminous indicated by a mean ANCK of $1.05 \pm 0.02$, with a range of 1.0 to 1.1. They have a mean $\mathrm{Si}_{2} \mathrm{O}$ content of $71.9 \pm 2.0 \mathrm{wt} \%$ (with a range of 68.4 to $75.1 \mathrm{wt} \%$ ), a mean $\mathrm{K}_{2} \mathrm{O}$ content of $5.55 \pm 0.30 \mathrm{wt} \%$, and a mean $\mathrm{Rb}$ content of $322.00 \pm 68.52 \mathrm{ppm} .{ }^{207} \mathrm{~Pb} /{ }^{206} \mathrm{~Pb}$ dating of zircon yielded similar ages for the two bodies: $380 \pm$ $4 \mathrm{Ma}$ (Zartman and Gallego 1979) and $380 \mathrm{Ma}$ (Wones and Ayuso 1993) for the Lucerne pluton, and $384 \pm 5 \mathrm{Ma}$ (Ludman et al. 1999) for the Deblois pluton. U-Pb dating of zircon in 2014 by the LA-ICP-MS method yielded a concordia age of $386.1 \pm 2.3 \mathrm{Ma}$ (Wang and McFarlane, unpublished data) for the Lucerne pluton.

The granitic mylonite and ultramylonite in contact with the Great Pond Formation and Turner Mountain syenite is separated from the Lucerne-Deblois pluton by a thin septum of Bucksport Formation (Fig. 1a). It was mapped previously either as the Mixer Pond Member of the Passagassawakeag Gneiss (Wones and Ayuso 1993) or as part of the Lucerne pluton in the Great Pond quadrangle (Wang 2011). Recent study (Wang 2014), however, revealed its protolith as leucogranite, differing from the Lucerne granite mineralogically by having much more quartz and plagioclase, higher plagioclase:potassium feldspar ratios, and in some cases muscovite. The leucogranite is present as NE-trending dikes (Fig. 1a). It locally shows a migmatitic appearance due to repeated, diffusive emplacement of leucogranitic magmas along the bedding or foliation in the host metasedimentary rocks.

\section{The Norumbega Fault System}

The shallow-crustal segment of the Norumbega fault system in eastern and east-central Maine has experienced a multi-deformational history involving distinctive ductile and brittle phases in chlorite-grade, lower greenschist rocks, and the granites that intrude them (Table 1; Ludman 1998; Wang and Ludman 2002, 2004; Wang 2007).

In the Turner Mountain area, initial Norumbega ductile shearing produced a ductile shear zone at least $1.5 \mathrm{~km}$ wide on the northwestern side of the Lucerne-Deblois plutons. Fine- to extremely fine-grained leucogranitic and metasedimentary mylonite and ultramylonite were the result of extremely high-strain grain-size reduction. The septum of metasedimentary rocks of the Bucksport Formation within the shear zone was ductilely sheared into phyllonite. Subsequently, episodic brittle fault reactivation (Table 1; Wang and Ludman 2002) locally developed a zone of coarse fault breccia and finer grained cataclasite in the ductilely deformed leucogranitic mylonite and phyllonite zone. Several narrow pull-apart basins were also produced, one of which hosts the Great Pond Formation in the Turner Mountain area. The pull-apart basins were themselves later faulted by significant dip-slip motion in the fault zone. This brittle faulting was concentrated along the northwestern margin of the leucogranitic mylonite and ultramylonite zone (Fig. 1a), forming a through-going brittle fault zone about $40 \mathrm{~m}$ wide that separates the ductile shear zone from the Turner Mountain syenite and redbeds.

\section{GEOLOGY OF THE TURNER MOUNTAIN SYENITE}

The Turner Mountain syenite stock has a surface area expression of about $2 \mathrm{~km}^{2}$, extends laterally for about $2.75 \mathrm{~km}$, and is roughly tabular in cross-section (Fig. 1b). Syenite is rare in the Coastal Maine Magmatic Province. Indeed, the Turner Mountain body is the only example in the shallow crustal rocks of eastern Maine and the Lincoln syenite is the only example in the deeper crustal area to the southwest.

Table1. Episodic faulting history of the Norumbega fault system in eastern and eastern-central Maine (Wang and Ludman 2002, 2004).

\begin{tabular}{c|c|c|c|c}
\hline \multicolumn{2}{c|}{ Events } & Kinematics & Mechanism & Timing \\
\hline & Episode-3 & Sinistral-reverse & Cataclastic flow & Pennsylvanian to Permian (?) \\
\hline & Episode-2 & Dextral strike-slip & Cataclastic flow & Mississippian \\
\hline & Episode-1 & High-angle reverse & Cataclastic flow & Between Middle Devonian and Mississippian \\
\hline \multicolumn{2}{c|}{ Ductile-Brittle } & \multicolumn{2}{|c}{ Initiation of Episode-1. Only minor conjugate ductile-brittle faults observed. } \\
\hline
\end{tabular}




\section{Contact Relationships}

The Turner Mountain syenite is bounded by high-angle faults that juxtapose it with the leucocratic mylonite/ultramylonite (Fig. 2a) to the southeast and Great Pond Formation redbeds to the northwest (Fig. 1a). Detailed mapping across the contacts revealed no evidence for an unconformity with the younger redbeds, or for contact metamorphism. To the southeast, both the syenite and leucogranitic mylonite/ultramylonite are strongly brecciated over a distance up to $40 \mathrm{~m}$ wide (Figs. 2a). Slickensides within the brittle fault zone dip moderately to steeply southeast (55$75^{\circ}$ ) and slickenlines show multiple displacements including dip-slip, oblique-slip, and sub-strike-slip motions.

On the northwestern side, the zone of cataclasized syenite and redbeds is narrower, about 15-25 m wide. Infiltration of chlorite-rich hydrothermal veins into siltstone and mudstone of the Great Pond Formation has altered the rocks next to the fault to a distinctive green not observed elsewhere in the unit. Potassic feldspar megaphenocrysts in the syenite next to the fault are fractured and commonly broken into smaller fragments (Fig. 2b). The fault contact on the northwestern side of the Turner Mountain syenite also dips toward the southeast, somewhat more steeply $\left(61-85^{\circ}\right)$ than the southeastern contact, making the Turner Mountain syenite sit on top of the younger redbeds. Slickenlines plunge steeply, with a pitch of $70-75^{\circ}$ to the northeast, suggesting a simpler deformation history of dip-slip offset (Fig. 2c).

\section{Lithology}

The Turner Mountain syenite is texturally and mineralogically relatively homogeneous, with the exception of textural variations locally at the margins that make up only a small percentage of the body. The dominant rock is a dark brown to black porphyritic biotite-amphibole syenite, with much lighter color weathered surfaces due to alteration of feldspars to clay. On weathered surfaces, large pink potassic feldspar phenocrysts up to $2-6 \mathrm{~cm}$ long are abundant (Fig. 3a) and are generally homogeneous, with a moderate percentage showing perthitic intergrowths. These large potassic feldspars are set in a medium- to coarse-grained groundmass composed of potassic feldspar, amphibole, biotite, and some plagioclase feldspar (Fig. 3b). Some biotite seems to be formed from amphibole. Anhedral quartz grains in the groundmass make up less than $5 \%$ of the rock. Apatite, zircon, monazite, rutile, uraninite, thorite, and brabantite occur as accessory minerals.

Small, dark enclaves of medium- to fine-grained alkaline (also potassic feldspar-rich) and more mafic rocks have been observed (Fig. 3c). Enclave mineralogy is similar to the matrix mineralogy of the enclosing porphyritic syenite.

A finer grained marginal phase containing less abundant potassic feldspar phenocrysts and more abundant medium-grained groundmass crops out locally around the margin of the stock. Small xenoliths of metasedimentary rocks
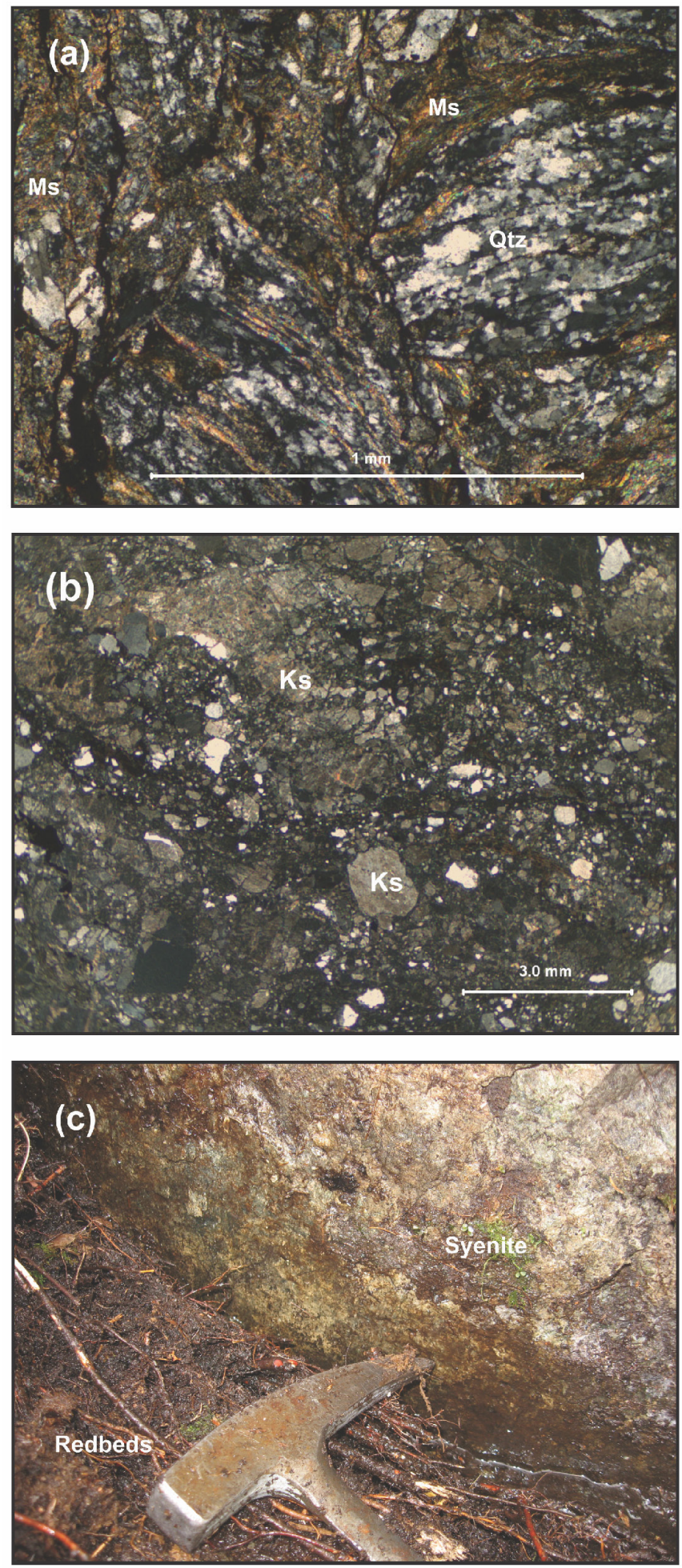

Figure 2. Photomicrographs of the cataclasized leucogranitic mylonite (a) and syenite (b). Both use cross-polarized light. Ms for muscovite, Ks for potassic feldspar, and Qtz for quartz. Photograph (c) shows slickensides on the fault contact between the syenite and the redbeds; Viewer faces east. 
similar to the Bucksport or Flume Ridge formations have been observed in this porphyritic marginal phase (Fig. 3d).

Hydrothermal secondary minerals including chlorite, calcite, and sericite occur commonly as small veins (Fig. 3e) at microscopic scale and fill cracks within potassic feldspar crystals (Fig. 3f). Alteration of amphibole and biotite to chlorite occurs throughout the stock, but is most prominent along its fault-contact margins.

\section{GEOCHEMISTRY OF THE TURNER MOUNTAIN SYENITE}

\section{Analytical Methods}

Five representative samples of Turner Mountain syenite were collected for comprehensive geochemical analysis performed at the State Key Laboratory of Geologic Processes and Mineral Resources of the Chinese University of Geoscience at Wuhan, China. Major elements were analyzed using XRF and trace elements using ICP-MS. The samples were crushed to about $1 \mathrm{~mm}$. A split was then ground in an agate mill and passed through a 160 mesh sieve for geochemical and isotopic analyses. Before isotopic analysis, the powder samples were leached using distilled $6 \mathrm{~N} \mathrm{HCl}$ at $100^{\circ} \mathrm{C}$ for 4 hours in order to remove secondary minerals and alteration products. Major element compositions were determined by wet chemical methods. The analytical errors for major oxides are less than $2 \mathrm{wt} \%$. For trace elemental analyses, samples (ca. $50 \mathrm{mg}$ ) were weighed, dissolved in distilled $\mathrm{HF}+\mathrm{HNO}_{3}$ (3:1) in Savillex Teflon screw-cap capsules at $100^{\circ} \mathrm{C}$ for 2 days, dried and then digested with $6 \mathrm{M}$ $\mathrm{HCl}$ at $150^{\circ} \mathrm{C}$. A blank solution was prepared and the total procedural blanks were $<50 \mathrm{ng}$ for all the analyzed trace elements. Three duplicates of three international standards (AGV-1, GSR-3, and DNC-1) were prepared using the same procedure in order to monitor analytical precision. The solutions were analyzed using a POEMS-III ICP-mass spectrometer. The discrepancy among triplicates is less than $10 \%$ for all elements, and the analyses of standards are in agreement with the recommended values.

$\mathrm{Sr}-\mathrm{Nd}$ isotopic compositions were determined on a Finnigan MAT-261 mass spectrometer operated in static mode. Samples were digested in Teflon bombs with a mixture of concentrated $\mathrm{HF}, \mathrm{HNO}_{3}$, and $\mathrm{HClO}_{4}$. Columns of AG50W-X8 and HDEHP resins were used sequentially for separation and purification of REEs and finally for separation of $\mathrm{Nd}$ and $\mathrm{Sm}$ by $\mathrm{HCl}$ eluants. The measured $\mathrm{Sr}$ and $\mathrm{Nd}$ isotopic ratios were normalized to ${ }^{86} \mathrm{Sr} /{ }^{88} \mathrm{Sr}=0.1194$ and ${ }^{146} \mathrm{Nd} /{ }^{144} \mathrm{Nd}=0.7219$. The La Jolla standard measured during the course of analyses yielded ${ }^{143} \mathrm{Nd} /{ }^{144} \mathrm{Nd}=0.511844$ \pm 1 and NBS987 gave ${ }^{87} \mathrm{Sr} /{ }^{86} \mathrm{Sr}=0.710331 \pm 5$. The total procedural blank was less than 2-5 ng for Sr and $5 \mathrm{ng}$ for $\mathrm{Nd}$. Analytical errors for $\mathrm{Sr}$ and $\mathrm{Nd}$ isotopic ratios are given as $2 \sigma$.

\section{Results}

Results of the major and trace elemental chemical analyses of the five samples shown in Table 2 confirm the homogeneity of the Turner Mountain syenite (Table 2). Silica content varies from $58.68-65.11 \mathrm{wt} \%$, the latter near the upper range for intermediate igneous rocks. $\mathrm{Na}_{2} \mathrm{O}$ contents are typical of intermediate rocks, but $\mathrm{K}_{2} \mathrm{O}$ contents are very high, as are $\mathrm{K}_{2} \mathrm{O} / \mathrm{Na}_{2} \mathrm{O}$ ratios (2.75 to 4.15$)$. The Turner Mountain syenite is ultrapotassic according to the definition of Foley et al. (1987) because of its $\mathrm{K}_{2} \mathrm{O}$ content (>3\% wt\%), $\mathrm{K}_{2} \mathrm{O} / \mathrm{Na}_{2} \mathrm{O}$ ratio (>2.0), and average $\mathrm{MgO}$ content (> $3 \% \mathrm{wt} \%)$.

Trace element abundances differ slightly for the five samples but distribution patterns normalized to primitivemantle (Fig. 4a) and chondrite values (Fig. 4b) are very similar. The syenite is enriched in light rare earth elements and depleted in heavy rare earth elements. The more incompatible elements, in particular $\mathrm{Rb}, \mathrm{Ba}, \mathrm{Th}, \mathrm{U}$, and $\mathrm{Pb}$, are strongly enriched relative to all other elements. High contents of $\mathrm{Ba}$ and $\mathrm{Pb}$ are consistent with the abundant amount of potassic feldspar in the syenite as these elements are typically enriched in potassic feldspars. Distinct negative anomalies are seen for $\mathrm{Nb}, \mathrm{Ta}, \mathrm{La}$, and $\mathrm{Ce}$ (relative to $\mathrm{U}$ and $\mathrm{Pb}$ ), $\mathrm{Sr}$ (relative to $\mathrm{Pr}$ and $\mathrm{Nd}$ ), and $\mathrm{Ba}$ (relative to $\mathrm{Rb}$ and $\mathrm{Th}$ ). The syenite is relatively depleted in the high field strength elements such as $\mathrm{Nb}$ and $\mathrm{Ta}$.

Whole-rock Rb-Sr and Sm-Nd isotopic data from the five syenite samples are presented in Table 3 . All of the samples show initial Sr ratios $\left(\left({ }^{87} \mathrm{Sr} /{ }^{86} \mathrm{Sr}\right) \mathrm{i}=0.7038-0.7068\right)$, higher than modern depleted mantle rocks of about 0.7026 , and low $\varepsilon_{\mathrm{Nd}}$ values of -4.38 to -4.49 . The $\varepsilon_{\mathrm{Nd}}(\mathrm{t})$ values are similar to those of the Lincoln syenite but the initial $\mathrm{Sr}$ ratios are lower than those of the Lincoln syenite (Fig. 5).

\section{ZIRCON U-Pb GEOCHRONOLOGY}

Two samples were collected from the Turner Mountain syenite for $\mathrm{U}-\mathrm{Pb}$ geochronology, and processed by Robert Ayuso at the U. S. Geological Survey. The samples were first crushed using a conventional crushing method and separated using heavy liquids and a magnetic separator. More than 100 zircon grains were hand-picked from each sample. The zircon grains were later dated using LA-ICP-MS at the State Key Laboratory of Geologic Processes and Mineral Resources of the Chinese University of Geoscience at Wuhan, China. Prior to LA-ICP-MS analysis, reflected light and cathodoluminescence images were obtained. Based on the images, most zircon grains are euhedral or nearly euhedral in shape and most zircon grains have well-developed oscillatory zoning (Fig. 6), characteristic of zircons of magmatic origin. Some zircon grains have homogeneous cores rimed by oscillatory zones.

Zircon 91500 was used as an external standard for age calibration and the NIST SRM 610 silicate glass was applied for the instrument optimization. The crater diameter was 

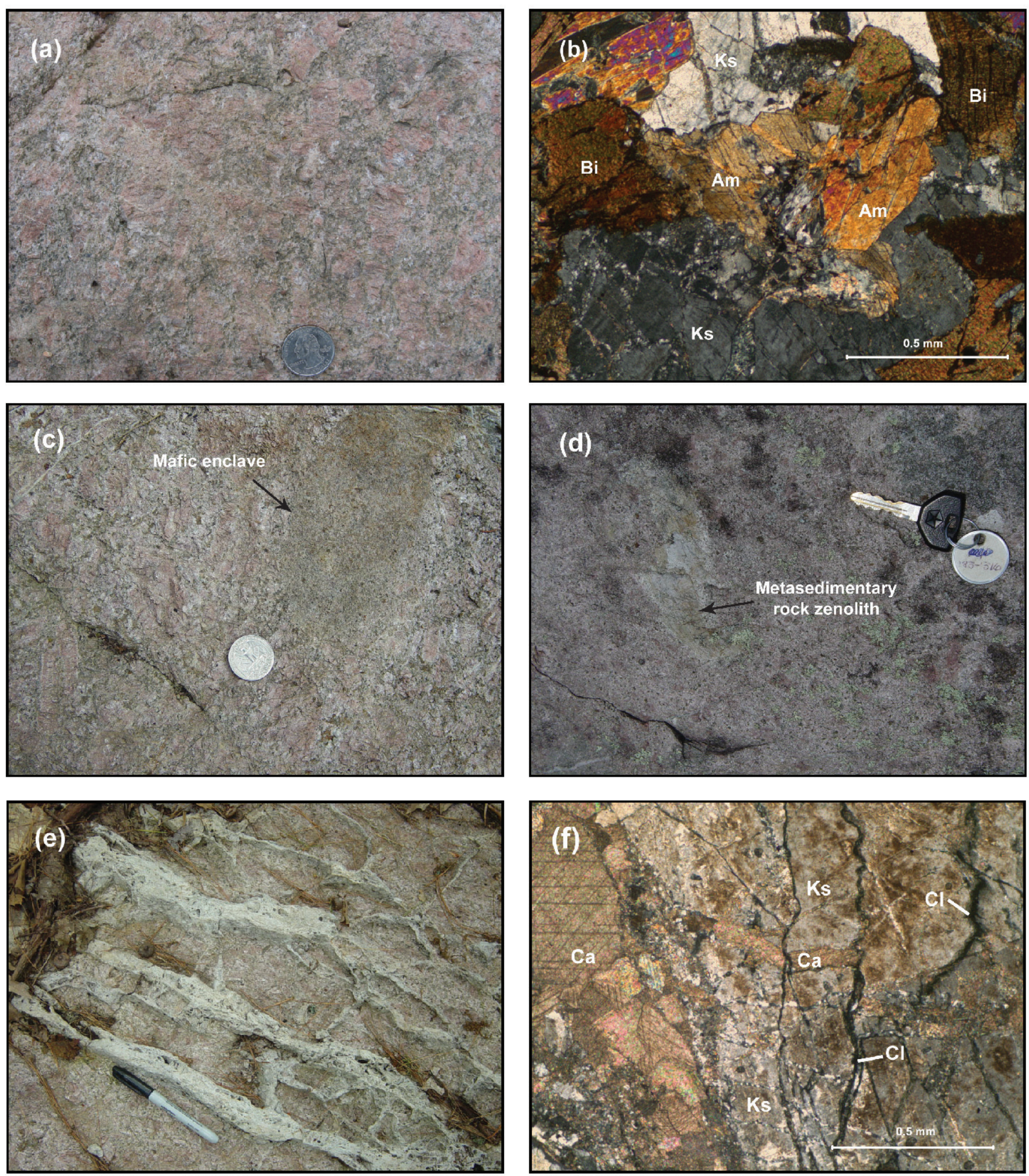

Figure 3. Photographs and photomicrographs of the syenite. See the text for explanation. Photomicrographs (b) and (f) use cross-polarized light. In (b) and (f), Am for amphibole, Bi for biotite, Ks for potassic feldspar, $\mathrm{Cl}$ for chlorite, and Ca for calcite. 
Table 2. Major and trace element contents of the Turner Mountain syenite.

\begin{tabular}{|c|c|c|c|c|c|}
\hline Sample & TM-1 & TM-2 & TM-3 & TM-4 & TM-5 \\
\hline $\mathrm{SiO}_{2}(\mathrm{wt} \%)$ & 61.05 & 59.97 & 58.68 & 59.99 & 65.11 \\
\hline $\mathrm{Al}_{2} \mathrm{O}_{3}$ & 14.85 & 14.86 & 15.20 & 13.76 & 14.49 \\
\hline $\mathrm{TiO}_{2}$ & 1.25 & 1.11 & 1.20 & 1.35 & 0.82 \\
\hline $\mathrm{Na}_{2} \mathrm{O}$ & 2.01 & 1.91 & 1.87 & 1.66 & 2.53 \\
\hline $\mathrm{K}_{2} \mathrm{O}$ & 7.63 & 7.93 & 7.16 & 6.41 & 6.95 \\
\hline $\mathrm{CaO}$ & 1.43 & 1.60 & 1.65 & 1.77 & 0.85 \\
\hline $\mathrm{Fe}_{2} \mathrm{O}_{3}$ & 1.21 & 1.19 & 1.30 & 1.40 & 0.84 \\
\hline $\mathrm{FeO}$ & 3.38 & 3.45 & 3.98 & 3.95 & 2.85 \\
\hline $\mathrm{MgO}$ & 3.55 & 3.89 & 4.58 & 4.92 & 2.81 \\
\hline $\mathrm{MnO}$ & 0.05 & 0.05 & 0.06 & 0.07 & 0.06 \\
\hline $\mathrm{P}_{2} \mathrm{O}_{5}$ & 0.52 & 0.47 & 0.49 & 0.56 & 0.30 \\
\hline $\mathrm{H}_{2} \mathrm{O}^{+}$ & 2.48 & 2.55 & 3.07 & 3.10 & 2.05 \\
\hline $\mathrm{CO}_{2}$ & 0.28 & 0.71 & 0.50 & 0.77 & 0.07 \\
\hline Total & 99.69 & 99.69 & 99.74 & 99.71 & 99.73 \\
\hline $\mathrm{Be}(\mathrm{ppm})$ & 19.77 & 13.07 & 9.26 & 19.48 & 18.40 \\
\hline B & 5.75 & 10.21 & 8.55 & 12.75 & 5.51 \\
\hline Sc & 12.79 & 11.65 & 13.44 & 13.56 & 8.86 \\
\hline V & 122.02 & 140.85 & 147.26 & 152.50 & 99.50 \\
\hline $\mathrm{Cr}$ & 228.45 & 209.08 & 218.16 & 285.02 & 109.76 \\
\hline Co & 16.68 & 18.47 & 19.62 & 22.13 & 12.20 \\
\hline $\mathrm{Ni}$ & 91.46 & 91.83 & 97.36 & 118.92 & 51.24 \\
\hline $\mathrm{Cu}$ & 52.4 & 67.59 & 45.39 & 68.37 & 44.30 \\
\hline $\mathrm{Zn}$ & 61.85 & 67.43 & 71.08 & 78.81 & 67.15 \\
\hline $\mathrm{Ga}$ & 25.40 & 26.41 & 26.87 & 25.84 & 23.51 \\
\hline $\mathrm{Rb}$ & 365.53 & 366.66 & 350.66 & 306.31 & 367.24 \\
\hline $\mathrm{Sr}$ & 367.99 & 462.18 & 301.64 & 355.19 & 236.16 \\
\hline Y & 28.72 & 25.19 & 33.75 & 36.20 & 23.82 \\
\hline $\mathrm{Zr}$ & 1204 & 1046 & 1166 & 1229 & 627 \\
\hline $\mathrm{Nb}$ & 80.39 & 64.66 & 79.93 & 77.08 & 59.86 \\
\hline $\mathrm{Cd}$ & 0.19 & 0.17 & 0.20 & 0.20 & 0.12 \\
\hline Sn & 15.30 & 13.61 & 15.29 & 14.63 & 12.88 \\
\hline Cs & 8.54 & 8.50 & 7.27 & 8.22 & 8.59 \\
\hline $\mathrm{Ba}$ & 1324 & 1658 & 1424 & 1394 & 1303 \\
\hline $\mathrm{La}$ & 84.37 & 88.18 & 76.25 & 82.34 & 85.76 \\
\hline $\mathrm{Ce}$ & 178.46 & 182.73 & 160.42 & 171.75 & 171.67 \\
\hline $\operatorname{Pr}$ & 21.21 & 20.97 & 20.15 & 21.30 & 19.00 \\
\hline $\mathrm{Nd}$ & 79.75 & 77.42 & 76.98 & 81.65 & 67.67 \\
\hline $\mathrm{Sm}$ & 14.26 & 13.65 & 14.43 & 15.37 & 11.44 \\
\hline $\mathrm{Eu}$ & 2.60 & 2.72 & 2.96 & 2.79 & 2.07 \\
\hline Gd & 9.04 & 8.54 & 9.54 & 10.28 & 7.36 \\
\hline $\mathrm{Tb}$ & 1.17 & 1.07 & 1.28 & 1.38 & 0.96 \\
\hline Dy & 5.80 & 5.16 & 6.53 & 6.96 & 4.74 \\
\hline Ho & 0.99 & 0.90 & 1.13 & 1.22 & 0.83 \\
\hline Er & 2.78 & 2.42 & 3.05 & 3.30 & 2.28 \\
\hline $\mathrm{Tm}$ & 0.37 & 0.34 & 0.43 & 0.45 & 0.33 \\
\hline $\mathrm{Yb}$ & 2.53 & 2.22 & 2.89 & 3.00 & 2.13 \\
\hline $\mathrm{Lu}$ & 0.37 & 0.33 & 0.43 & 0.44 & 0.32 \\
\hline Hf & 35.18 & 30.16 & 33.94 & 35.62 & 19.78 \\
\hline $\mathrm{Ta}$ & 5.23 & 4.45 & 5.41 & 5.07 & 4.65 \\
\hline $\mathrm{Pb}$ & 79.84 & 97.32 & 70.38 & 83.91 & 85.13 \\
\hline Th & 84.37 & 104.95 & 117.95 & 126.01 & 112.54 \\
\hline $\mathrm{U}$ & 19.37 & 20.76 & 22.28 & 20.69 & 21.88 \\
\hline
\end{tabular}

$30 \mu \mathrm{m}$ during the analyses. The instrument parameters and detailed procedures were described by Liu et al. (2008). The ICPMS DataCal (Ver. 6.7, Liu et al. 2008, 2010) and Isoplot (Ver. 3.0, Ludwig 2003) programs were used for data reduction. Correction for common $\mathrm{Pb}$ was made following Anderson (2002). Errors on individual analyses by LA-ICPMS are quoted at the $1 \sigma$ level, while errors on pooled ages are quoted at the $95 \%(2 \sigma)$ confidence level.

Table 4 shows the $\mathrm{U}-\mathrm{Pb}$ isotopic data of the individual analytical spots. Figure 7 a shows a U-Pb concordia diagram for the analyzed zircon grains. U-Pb data yield a weighted mean age of $410.5 \pm 2.4 \mathrm{Ma}$ (MSWD of concordance $=0.16$, weighted by data-point errors only, 0 of 17 rejection; $95 \%$ confidence; probability of concordance $=1.000$ ) (Fig. 7b). The age indicates that the Turner Mountain syenite is part of the Late Silurian-Early Devonian magmatism in Maine, which also includes the Lincoln syenite (418 Ma).

\section{COMPARISON WITH OTHER PLUTONS IN THE REGION}

The Turner Mountain syenite differs markedly in chemistry, mineralogy, and age from its closest plutonic neighbors - the Deblois and Lucerne granites. These plutons have significantly higher mean $\mathrm{SiO}_{2}$ compositions (71.9 $\pm 2.0 \mathrm{wt} \%$ ) than the Turner Mountain body (58-65\% wt $\%)$ and are far less potassic, suggesting that they were produced by different processes than the syenite. They are also 24 million years younger, indicating that they were produced during a different stage in tectonic evolution of the region.

In contrast, the Turner Mountain syenite has strong similarities to the Lincoln syenite in south-central Maine. Both bodies have similar major element proportions - notably $\mathrm{SiO}_{2}$ and $\mathrm{K}_{2} \mathrm{O}\left(\mathrm{K}_{2} \mathrm{O}=6.41-7.93 \mathrm{wt} \%\right.$ for the Turner Mountain syenite vs. $6.14-7.17 \mathrm{wt} \%$ for the Lincoln syenite), although the Turner Mountain syenite is slightly enriched in these oxides and has less MgO. Their trace element characteristics are also similar, although not identical (Fig. 4). Both are enriched in large ion lithophile elements and have high contents of light rare earth elements. For example, the Turner Mountain syenite contains 1303-1658 ppm $\mathrm{Ba}, 306-367 \mathrm{ppm} \mathrm{Rb}$, and 236-462 ppm Sr and the Lincoln syenite has 1467-2410 ppm Ba, 278-444 ppm Rb, and 503-890 ppm Sr. The two plutons also have similar isotopic signatures, with essentially the same $\varepsilon_{\mathrm{Nd}}$ values and an overlap in ${ }^{87} \mathrm{Sr} /{ }^{86} \mathrm{Sr}$ ratios although most ${ }^{87} \mathrm{Sr} /{ }^{86} \mathrm{Sr}$ ratios for the Lincoln syenite are slightly higher than those of the Turner Mountain syenite (Fig. 5).

The ultrapotassic character of the two syenite bodies is unique in the region, which suggests (1) that the two magmas were most likely generated by similar processes and (2) that the conditions necessary for their generation were geographically and temporally restricted. The case would be stronger, however, if the two plutons were the same age, and the $8 \mathrm{Myr}$ interval between their crystallization ages is somewhat problematic. It could be a measure of how long 

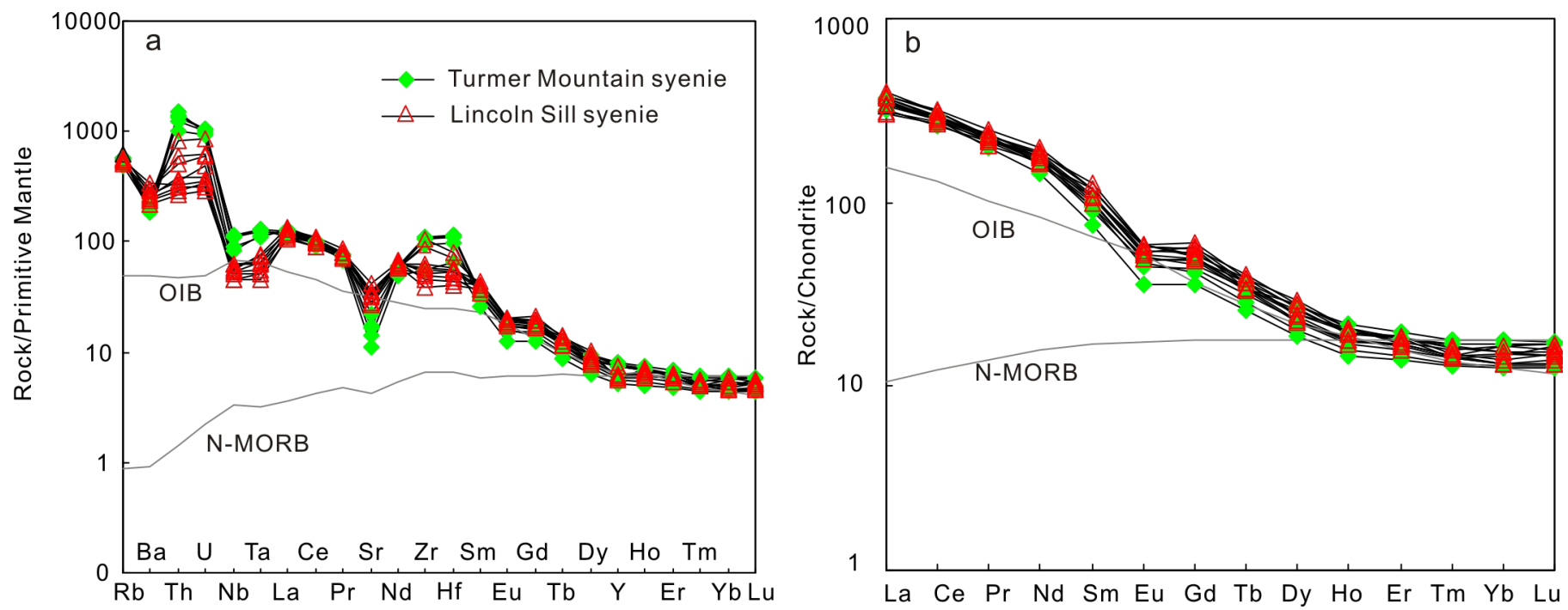

Figure 4. Primitive mantle-normalized pattern of trace elements (a) and chondrite-normalized REE pattern (b) of the Turner Mountain syenite and Lincoln syenite. Data for the Lincoln Sill syenite is from West et al. (2007) for comparison. Primitive mantle normalization standard values and OIB and N-MORB values are from Sun and McDonough (1989) and chondrite normalization standard values are from McDonough and Sun (1995).

Table 3. Rb-Sr and Sm-Nd isotopic data of the Turner Mountain syenite.

\begin{tabular}{|c|c|c|c|c|c|c|c|c|c|c|c|c|c|c|c|}
\hline Sample & Age (Ma) & $\mathrm{Pb}$ & $\mathrm{Sr}$ & ${ }^{87} \mathrm{Sr} /{ }^{86} \mathrm{Sr}$ & $2 \sigma$ & $\left({ }^{87} \mathrm{Sr} /{ }^{86} \mathrm{Sr}\right) \mathrm{i}$ & $\varepsilon S r$ & $\mathrm{Sm}$ & $\mathrm{Nd}$ & ${ }^{147} \mathrm{Sm} /{ }^{144} \mathrm{Nd}$ & ${ }^{143} \mathrm{Nd} /{ }^{144} \mathrm{Nd}$ & $2 \sigma$ & $\mathrm{T}_{\mathrm{DM}}(\mathrm{Ga})$ & $\left({ }^{143} \mathrm{Nd} /{ }^{144} \mathrm{Nd}\right) \mathrm{i}$ & $\varepsilon N d$ \\
\hline TM-1 & 0.411 & 366 & 368 & 0.723335 & 2 & 0.706466 & 34.81 & 14.3 & 79.8 & 0.1072 & 0.51217 & 10 & 1.35 & 0.511878 & -4.49 \\
\hline TM-2 & 0.411 & 367 & 462 & 0.720287 & 5 & 0.706818 & 39.8 & 13.6 & 77.4 & 0.1276 & 0.512167 & 10 & 1.35 & 0.511881 & -4.44 \\
\hline TM-3 & 0.411 & 351 & 302 & 0.725558 & 5 & 0.705841 & 25.92 & 14.4 & 77 & 0.1091 & 0.512185 & 10 & 1.35 & 0.511881 & -4.45 \\
\hline TM-4 & 0.411 & 306 & 355 & 0.721213 & 3 & 0.706596 & 36.65 & 15.4 & 81.7 & 0.1206 & 0.512191 & 20 & 1.34 & 0.511884 & -4.38 \\
\hline TM-5 & 0.411 & 367 & 236 & 0.730236 & 6 & 0.703843 & -2.46 & 11.5 & 67.7 & 0.1155 & 0.51216 & 10 & 1.35 & 0.511884 & -4.39 \\
\hline
\end{tabular}

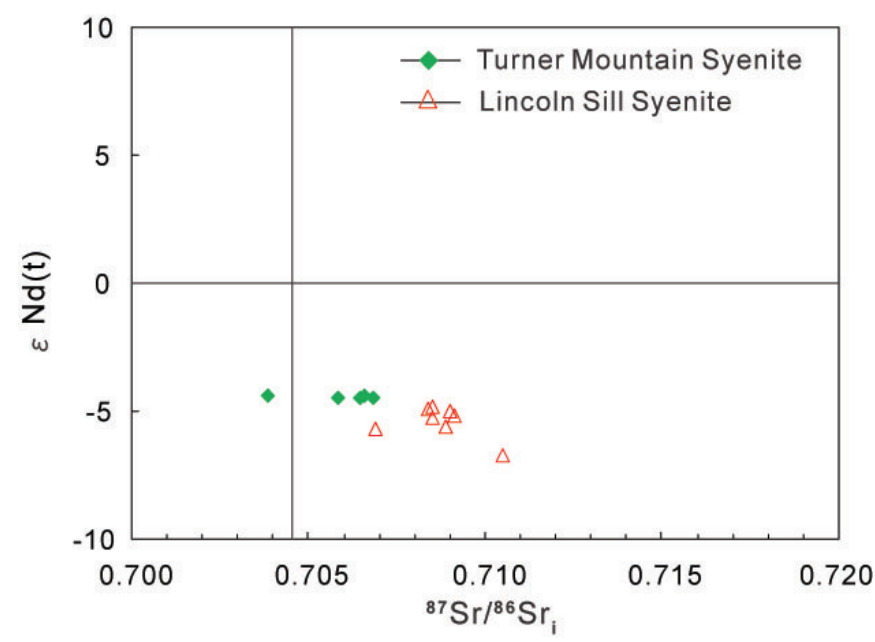

Figure 5. Initial $\varepsilon_{\mathrm{Nd}}(\mathrm{t})$ vs. ${ }^{87} \mathrm{Sr} /{ }^{86} \mathrm{Sr}_{\mathrm{i}}$ diagram for the Turner Mountain syenite. Data for the Lincoln syenite is from West et al. (2007) for comparison. the required conditions remained in effect, or might indicate a repetition of the required set of conditions. It is also possible that the processes responsible for the generation of the Lincoln and Turner Mountain syenite magmas were diachronous along strike.

While the strong textural, mineralogical, and geochemical similarities between the syenite bodies are emphasized in this study, it has to be pointed out that there exist some differences between them. For example, the Lincoln syenite contains orthopyroxene, clinopyroxene, and biotite without amphibole whereas the Turner Mountain syenite contains amphibole and biotite without pyroxenes. Geochemically the Lincoln syenite is slightly more mafic than the Turner Mountain syenite. Considering the $100 \mathrm{~km}$ distance between the plutons, their source regions cannot be identical due to heterogeneities in the lithospheric mantle and the crust. In addition, their magmas could have experienced different degrees of crustal interaction, resulting in differences reflected in mineralogy and chemistry (including isotopic chemistry), though the differences are not large. 

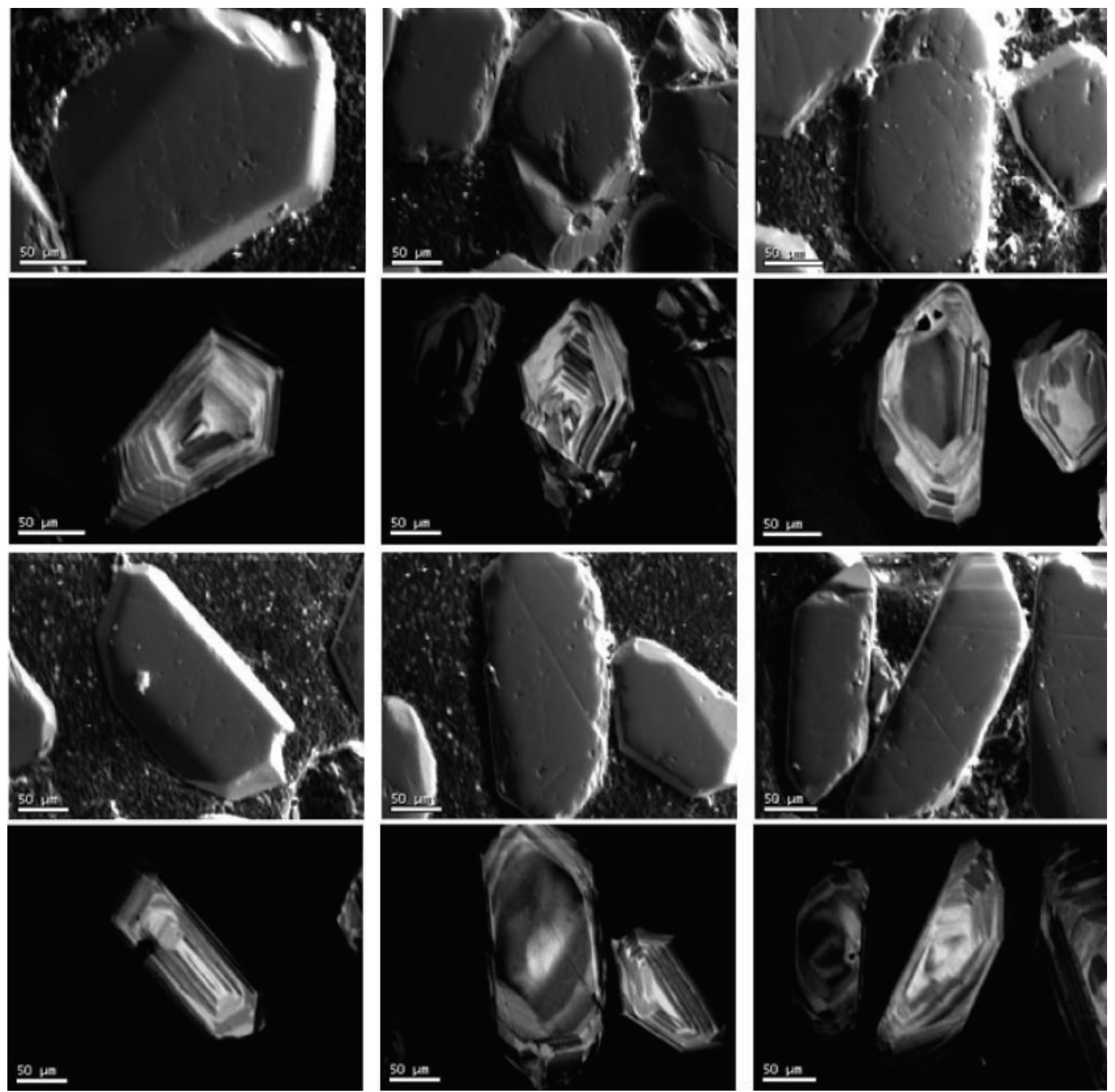

Figure 6. Cathodoluminescence images of some representative sample zircon crystals used in the LA-ICP-MS analysis. 

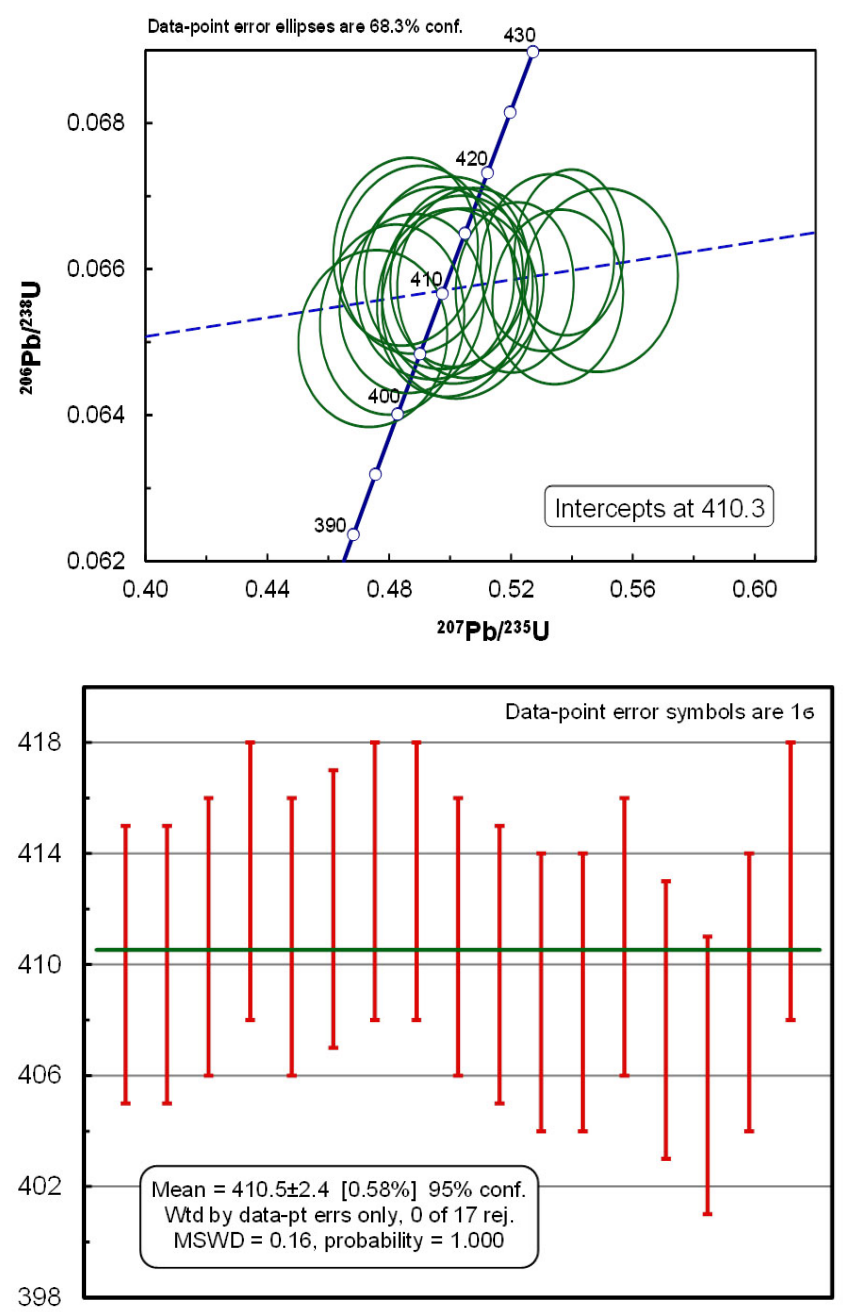

Figure 7. Zircon U-Pb concordia diagram (a) and weighted mean age (b) based on LA-ICP-MS analytic results.

\section{PETROGENESIS OF THE TURNER MOUNTAIN SYENITE}

A relative abundance of large-ion-lithophile elements in igneous rocks is typically attributed to derivation from the continental lithosphere (Rollinson 1993). However, the Turner Mountain syenite also contains relatively high contents of primitive $\mathrm{Mg}$ ( $\mathrm{MgO}$ 2.81-4.92 wt\%), $\mathrm{Ni}$ (average $90.2 \mathrm{ppm}$ ), and $\mathrm{Cr}$ (average $210 \mathrm{ppm}$ ) which are probably the result of differentiation of mantle-derived melts.

The weak Eu negative anomaly suggests that magma fractionation was involved in forming the Turner Mountain syenite. This interpretation is supported further by the trough in Sr values in the primitive mantle-normalized patterns (Fig. 4a) attributable to variable degrees of plagioclase fractionation. Both the Turner Mountain and the Lincoln syenites have high contents of light rare-earth elements and initial ${ }^{87} \mathrm{Sr} /{ }^{86} \mathrm{Sr}$ ratios similar to ocean-island basalts (the Lincoln syenite is slightly higher than the Turner Mountain syenite). The relatively narrow range of initial $\mathrm{Sr}$ ratios $\left(\left({ }^{87} \mathrm{Sr} /{ }^{86} \mathrm{Sr}\right)_{\mathrm{i}}=0.7038-0.7068\right)$ and narrow range of $\varepsilon_{\mathrm{Nd}}(\mathrm{t})$ values (-4.38 to -4.49$)$ that are not mantle-like suggest a relatively constant amount of crustal component is present in the Turner Mountain syenite. This crustal contamination probably occurred in the source since any additional crustal contamination would have caused an increase in $\left({ }^{87} \mathrm{Sr} /{ }^{86} \mathrm{Sr}\right) \mathrm{i}$ and a decrease in $\varepsilon_{\mathrm{Nd}}(\mathrm{t})$ values. Additionally, the primitive mantle-normalized pattern illustrates $\mathrm{Nb}$ amd $\mathrm{Ta}$ anomalies in relation to the light rare-earth elements (Fig. $5 a)$, which have been interpreted as typical of magma produced from sources affected by lithospheric subduction or delamination (Kay and Mahlburg-Kay 1991).

Three general models have been proposed to address the petrogenesis of syenite. The first one is called a "mixing model" in which mantle-sourced, silica-undersaturated alkaline magmas mix with magmas derived from the lower crust (e.g., Dorais 1990) or the mixing takes place between mafic and silicic melts with subsequent differentiation of the hybrid liquids (e.g., Sheppard 1995). In the Turner Mountain syenite, however, no evidence for magma mixing has been observed, although some dark, mafic enclaves are present in the syenite, but their mineralogy is not very different from that of the syenite. In addition, mixing would have reduced the concentrations of elements like $\mathrm{K}$ and $\mathrm{Ba}$. In the second model, syenite magmas are considered to originate by partial melting of crustal rocks resulting from an influx of volatiles (e.g., Lubala et al. 1994) or in a closed system at pressures typical of the base of over-thickened crust (e.g., Huang and Wyllie 1981). The relatively primitive nature of the Turner Mountain syenite characterized by $\mathrm{MgO}$ content (2.8-4.9 wt\%) and $\mathrm{Cr}$ (average $210.1 \mathrm{ppm}$ ) and $\mathrm{Ni}$ (average $90.2 \mathrm{ppm}$ ) concentrations makes the second model highly unlikely in this case. In addition, partial melting of any of the older crustal rocks in the deep crust would have produced high-Si, granitoid melts, which is not the case for the geochemically intermediate Turner Mountain syenite. The third model involves partial melting of metasomatized mantle (Sutcliffe et al. 1990; Lynch et al. 1993) or residual melts formed by differentiation of alkali basalt magma (e.g., Parker 1983; Thorpe and Tindle 1992). The "partial melting of metasomatized mantle" model was adopted by West $e t$ al. (2007) to address the petrogenesis of the Lincoln syenite.

As noted previously, comparison of the Turner Mountain and Lincoln syenite plutons show chemical and mineralogical similarities. Hence, the petrogenetic model involving partial melting of metasomatized mantle proposed by West et al. (2007) for the Lincoln syenite could also be applied to the Turner Mountain syenite. Following West et al. (2007), both syenite magmas might have formed by partial melting of a mantle wedge previously metasomatized by subduction-derived potassium-rich fluids. Decompression melting was made possible by extension associated with Late Silurian-Early Devonian slab breakoff or delamination following west-directed subduction. The extension that was superimposed on the previously metasomatized mantle wedge did not occur simultaneously in the two areas - it 


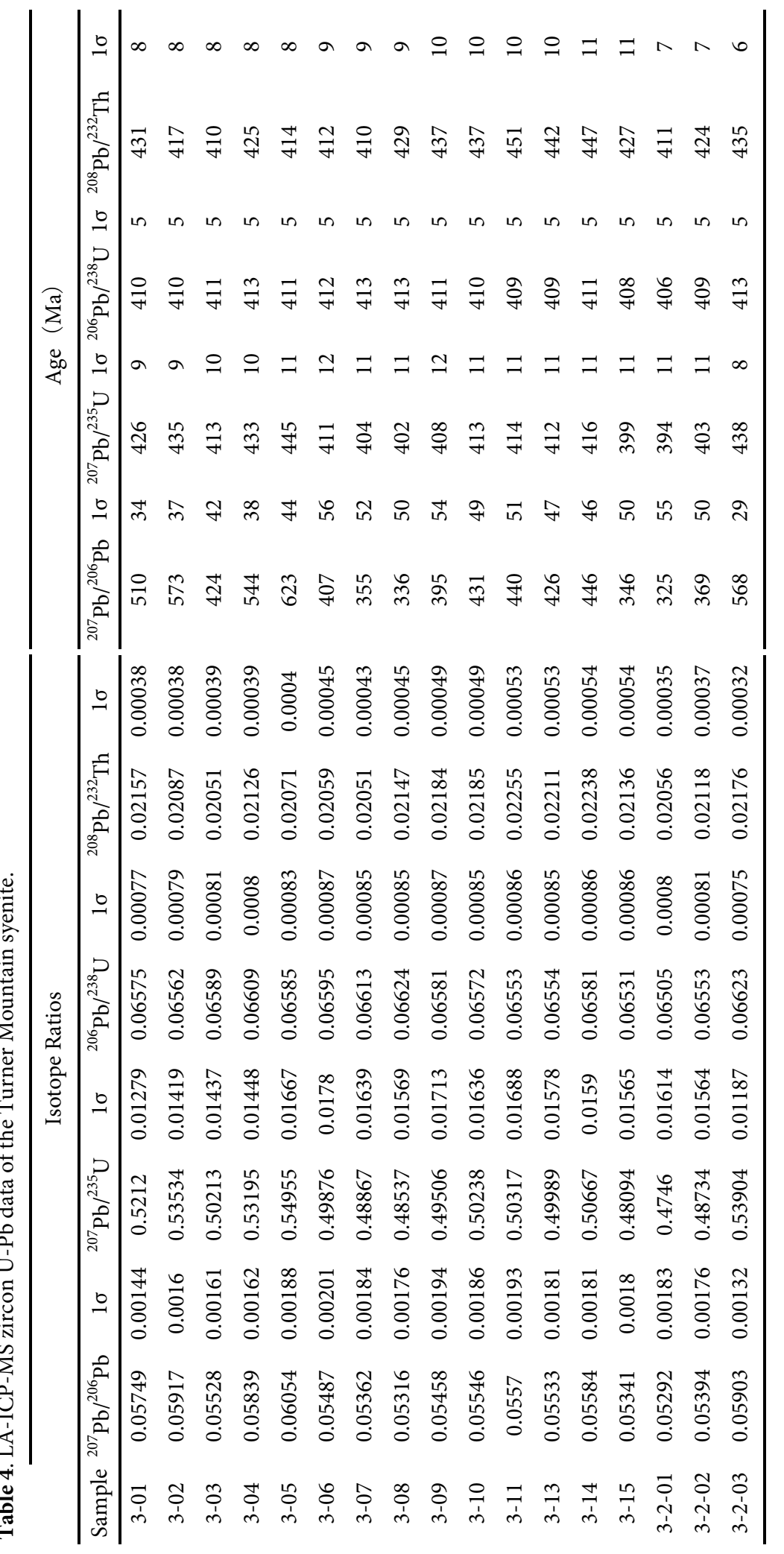


occurred first (418 Ma) in south-central Maine, and then roughly 8 million years later it affected the Turner Mountain area. Another scenario could be that the ultrapotassic magmatism lasted for about 8 m.y. during the Late SilurianEarly Devonian. Based on Sr-Nd isotopic compositions, the Turner Mountain syenite magma probably had more crustal interaction than the Lincoln syenite magma.

\section{POST-OROGENIC EXHUMATION: REACTIVATION(S) OF THE NORUMBEGA FAULT SYSTEM}

The three episodes of brittle fault reactivation (Table 1) that followed initial ductile shearing in the Norumbega fault system are also recognized in the Turner Mountain area and are, cumulatively, responsible for the current nonintrusive, fault-contact relationships of the Turner Mountain syenite with adjacent rocks. Small-scale structures and the presence of probable Turner Mountain clasts in the Great Pond Formation indicate that a three-step evolution led to the current tectonic relationships (Fig. 8).

The earliest through-going brittle faulting took place along the contact between the leucogranitic mylonite zone and the Flume Ridge Formation and is attributed to the first episode of brittle reactivation (Episode 1 in Table 1). Episode 1 was caused by transpression that resulted in highangle reverse faulting during which the Turner Mountain syenite, that had avoided previous ductile shearing, was uplifted as a fault sliver to a shallower crustal level than that at which it had been originally emplaced (Fig. 8a).

A later transtensional environment was superimposed on the Norumbega fault system, resulting in brittle dextral faulting and producing a number of small pull-apart basins during Reactivation Episode 2 (Fig. 8b). One of those basins extends nearly $30 \mathrm{~km}$ from Great Pond area to Chemo Pond area, and currently hosts redbeds of the Great Pond Formation; others farther to the northeast contain similar but unnamed conglomerate, sandstone, and mudstone (Wang and Ludman 2002). The redbeds include poorly sorted, immature pebble conglomerate and granule conglomerate, with finer grained sandstone, siltstone, and mudstone, and numerous layers of texturally immature arkose and arkosic conglomerate which contain considerable amount of angular potassic feldspar clasts. The only known local sources for the potassic feldspar clasts were the nearby Turner Mountain syenite and the Lucerne-Deblois plutons. We suggest that the Turner Mountain pluton was elevated and exhumed during Reactivation Episodes 1 and 2, weathered, and eroded, and shed potassic feldspar and LucerneDeblois granite clasts rapidly into the nearby intermontane pull-apart molasse basin.

Renewed transpressional activity (Reactivation Episode 3) followed, indicated by significant cataclasis along the contacts between the redbeds and the syenite, the leucogranitic mylonite and the syenite, and the redbeds and the Flume Ridge Formation (Fig. 8c). High-angle reverse faults (a) Episode-1: Reverse faulting (Post-ductile shearing reactivation)

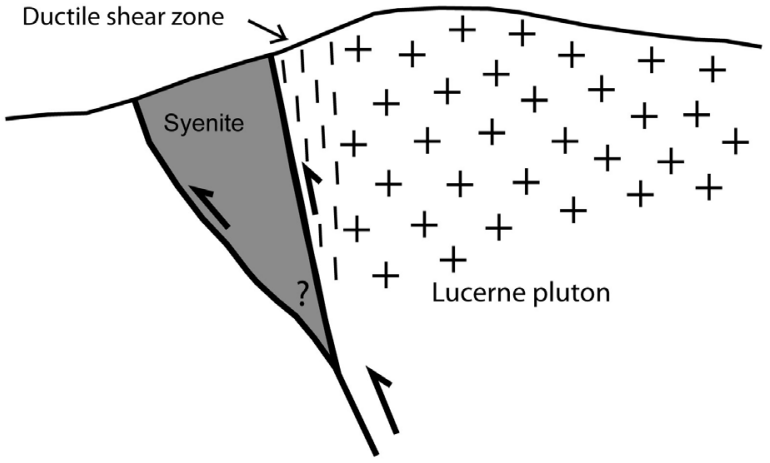

(b) Episode-2:Transtensional faulting (Post-Acadian, Mississippian?)

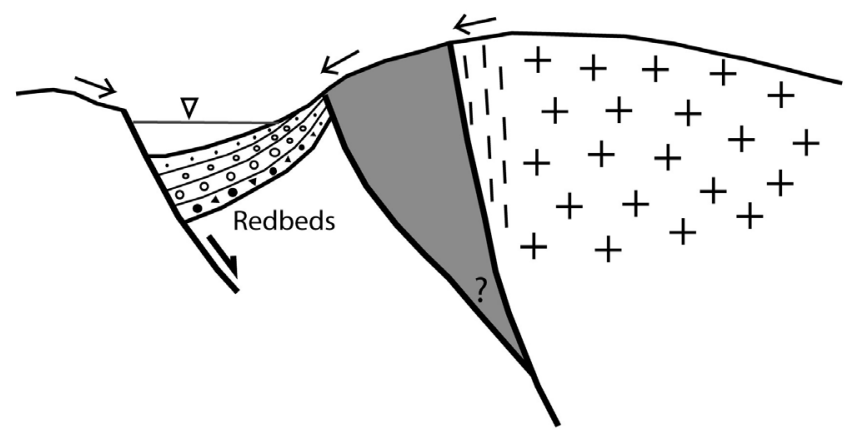

(c) Episode-3: Reverse faulting (Alleghanian?)

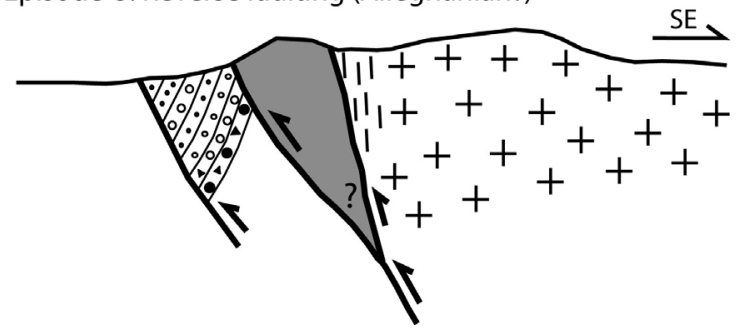

Figure 8. A schematic model showing exhumation of the Turner Mountain syenite along with the reactivation history of the Norumbega fault system. See the text for more detailed explanation.

rotated the subhorizontal redbeds in the pull-apart basin to their current steeply dipping attitudes and shortened the basin, uplifting the Turner Mountain syenite body to an even higher position in the crust.

\section{CONCLUSIONS}

Field, petrologic, geochemical, geochronological, and structural studies of the Turner Mountain syenite provide a clear picture of its age and origin and help understand the complex evolution of the shallow crustal segment of the Norumbega fault system. The Turner Mountain syenite:

(1) crystallized at $410.5 \pm 2.4 \mathrm{Ma}$, a time between Salinic bimodal plutonism (e.g., 423 Ma Pocomoonshine pluton) and post-Acadian bimodal plutonism (e.g., $386 \mathrm{Ma}$ Deblois-Lucerne plutons);

(2) is bounded by high-angle faults that separate it from younger leucogranitic mylonite and phyllonite to the south 
and unmetamorphosed redbeds to the north, with evidence for neither a contact metamorphic aureole nor an angular unconformity;

(3) was exhumed tectonically and structurally as a fault sliver, most probably during the last episode of transpressional reactivation of the Norumbega fault system;

(4) is mineralogically, geochemically, and temporally distinctly different from the nearby Lucerne and Deblois granites of the Coastal Maine Magmatic Province, but very similar to the Lincoln syenite exposed $100 \mathrm{~km}$ to the southwest - suggesting that, given the unique aspects of these two ultrapotassic magma bodies in the region, it is likely they formed by similar processes;

(5) and was probably produced by processes similar to those proposed by West et al. (2007) for the Lincoln syenite, although the apparent $8 \mathrm{Myr}$ time lag raises questions about the ambient thermal regimes in which the two plutons formed. Processes suggested by West et al. (2007) include westward-directed subduction followed by Late Silurian-Early Devonian slab break-off or delamination. The magma was probably generated by partial melting of a mantle wedge metasomatically enriched in potassium by fluids released during subduction.

Both the Turner Mountain syenite and the Lincoln syenite are evidence of rare ultrapotassic magmatism in the region, suggesting that the conditions required for their formation were restricted, as would be the case in the slab break-off model.

\section{ACKNOWLEDGEMENTS}

Funding for this work was provided by U. S. Geological Survey STATEMAP Program through the Maine Geological Survey, a University of Maine System Trustee Professorship, and the Zillman Family Professorship, to Chunzeng Wang. We thank Robert Marvinney and Henry Berry for their long-time logistic support and supervision throughout the project, and Dave West and Robert Ayuso for their constructive reviews that significantly improved the quality and the clarity of the manuscript. Robert Ayuso also helped with zircon selection. Martin Yates helped major and accessory mineral identification by using SEM. This work benefits from discussions with Gary Boone. Wang is also grateful for the field assistance provided by several Hunter College and University of Maine at Presque Isle undergraduate students in the past years, in particular Geoffery Nazzaro, Jay Raymond, and Jared Dickinson. Constructive reviews by two anonymous reviewers are greatly appreciated.

\section{REFERENCES}

Anderson, T. 2002. Correction of common lead in $\mathrm{U}-\mathrm{Pb}$ analyses that do not report ${ }^{204} \mathrm{~Pb}$. Chemical Geology, 192, pp. 59-79. http://dx.doi.org/10.1016/S00092541(02)00195-X
Dorais, M. J. 1990. Compositional variations in pyroxenes and amphiboles of the Belknap Mountain complex, New Hampshire: evidence for origin of silica-saturated alkaline rocks. American Mineralogist, 75, pp. 10921105.

Foley, S. F., Venturelli, G., Green, D. H., and Toscani, L. 1987. The ultrapotassic rocks: Characteristics, classification, and constraints for petrogenetic models: Earth Science Reviews, 24, pp. 81-134. http://dx.doi. org/10.1016/0012-8252(87)90001-8

Fyffe, L. R. 1988. Geology of Beaconsfield area (NTS 21 G/6e), Charlotte County, New Brunswick. New Brunswick Department of Natural Resources and Energy, Minerals and Energy Division, Plate 88-189 (revised 2002), scale 1:20 000 .

Gilman, R. A. 1974. Geologic mapping in the Ellsworth, Great Pond, Lead Mountain, Tug Mountain, and Wesley quadrangles, Maine. Maine Geological Survey, unpublished report and map

Griffin, J. R. 1976. Reconnaissance of bedrock geology of the Great Pond quadrangle, Maine. Maine Geological Survey, Open-File No. 76-22, scale 1:62 500.

Hogan, J. P. and Sinha, A. K. 1989. Compositional variation of plutonism in the coastal Maine magmatic province: mode of origin and tectonic setting. In Studies in Maine Geology: Igneous and Metamorphic Geology. Edited by R.D. Tucker and R.G. Marvinney. Maine Geological Survey, 4, pp.1-35.

Huang, W. L. and Wyllie, P. J. 1981. Phase relationships of S-type granite with $\mathrm{H}_{2} \mathrm{O}$ to $35 \mathrm{kbar}$ : muscovite granite from Harney Peak, South Dakota. Journal of Geophysical Research, 86, pp. 10515-10529. http://dx.doi. org/10.1029/JB086iB11p10515

Hubbard, M. S., West, D. P. Jr., Ludman, A., Guidotti, C. V., and Lux, D. R. 1995. The Norumbega Fault Zone, Maine: mid-shallow level crustal section within a transcurrent zone. Atlantic Geology, 33, pp. 109-116.

Kay, R. W. and Mahlburg-Kay, S. 1991. Creation and destruction of lower continental crust. Geologische Rundschau, 80(2), pp. 259-278. http://dx.doi. org/10.1007/BF01829365

Liu, Y. S., Hu, Z. C., Gao, S., Günther, D., Xu, J., Gao, C. G., and Chen, H. H. 2008. In situ analysis of major and trace elements of anhydrous minerals by LA-ICP-MS without applying an internal standard. Chemical Geology, 257, pp. 34-43. http://dx.doi.org/10.1016/j. chemgeo.2008.08.004

Liu, Y. S., Hu, Z. C., Zong, K. Q., Gao, C. G., Gao, S., Xu, J., and Chen, H. H. 2010. Reappraisement and refinement of zircon $\mathrm{U}-\mathrm{Pb}$ isotope and trace element analyses by LA-ICP-MS. Chinese Science Bulletin, 55, pp. 15351546. http://dx.doi.org/10.1007/s11434-010-3052-4

Loiselle, M. C. and Ayuso R. A. 1980. Geochemical characteristics of granitoids across the Merrimack synclinorium, eastern and central Maine. In The Caledonides in the USA: Proceedings, International 
Geological Conference Project No. 27. Edited by D.R Wones, Department of Geological Sciences, Virginia Polytechnic Institute and State University, Memoir 2, pp. 117-121.

Lubala, R. t., Frick, C., Roders, J. H., and Walraven, F. 1994. Petrogenesis of syenites and granites of the Schiel Alkaline complex, Northern Transvaal, South Africa. Journal of Geology, 102, pp. 307-309.

Ludman, A. 1998. Evolution of a transcurrent fault zone in shallow metasedimentary rocks: the Norumbega Fault Zone, eastern Maine. Journal of Structural Geology, 20, pp. 93-107. http://dx.doi.org/10.1016/S01918141(97)00094-1

Ludman, A. and West, D. P. Jr. 1999. Preface. In Norumbega Fault Zone of the Northern Appalachians. Edited by A. Ludman and D.P. West, Jr. Geological Society of America, Special Paper 331, pp. v-xii.

Ludman, A., Lanzirotti, A., Lux, D., and Wang, C. 1999. Constraints on timing and displacement of multiple shearing in the Norumbega Fault Zone, eastern Maine. In Norumbega Fault Zone of the Northern Appalachians. Edited by A. Ludman and D.P. West, Jr. Geological Society of America Special Paper 331, pp. 179-194. http://dx.doi.org/10.1130/0-8137-2331-0.179

Ludwig, K. R. 2003. User's Manual for ISOPLOT 3.00: a geochronological toolkit for Microsoft Excel. Berkeley Geochronology Center Special Publication, pp. 41-70.

Lynch, D. J., Musselman, T. E., Gutmann, J. T., and Patchett, P. J. 1993. Isotopic evidence for the origin of Cenozoic volcanic rocks in the Pinacate volcanic field, northwestern Mexico. Lithos, 29, pp. 295-302. http:// dx.doi.org/10.1016/0024-4937(93)90023-6

McDonough, W. F. and Sun, S. 1995. The composition of the Earth. Chemical Geology, 120, pp. 223-253. http:// dx.doi.org/10.1016/0009-2541(94)00140-4

Osberg, P. H., Hussey, A. M., II, and Boone, G. M. 1985. Bedrock geologic map of Maine: Maine Geologic Survey, Augusta, Maine, scale 1:500 000.

Parker, D.F. 1983. Origin of the trachyte-quartz trachyteperalkalic rhyolite suite of the Oligocene Paisano volcano, Trana-Pecos Texas. Geological Society of America Bulletin, 94, pp. 614-629. http://dx.doi. org/10.1130/0016-7606(1983)94<614:OOTTTR >2.0. $\mathrm{CO} ; 2$

Rollinson, H. R. 1993. Using Geochemical Data: Evaluation, Presentation, Interpretation. New York, Longman, $352 \mathrm{p}$.

Sheppard, S. 1995. Hybridization of shoshonitic lamprophyre and calc-alkaline granite magma in the Early Proterozoic Mt. Bundey igneous suite, Northern Territory. Australia Journal of Earth Science, 42, pp. 173-185. http://dx.doi. org/10.1080/08120099508728190

Stoesser, D. B. 1966. Geology of a portion of the Great Pond quadrangle, Maine. Unpublished M. Sc. thesis, University of Maine, Orono, Maine, $87 \mathrm{p}$.
Sun, S. -s. and McDonough, W. F. 1989. Chemical and isotopic systematics of oceanic basalts: implications for mantle composition and processes. In Magmatism in Ocean Basins. Edited by A.D. Saunders and M.J. Norry. Geological Society of London Special Publication, London, pp. 313-345.

Sutcliffe, R. H., Smith, A. R., Doherty, W., and Barnett, R. L. 1990. Mantle derivation of Archean amphibole-bearing granitoids and associated mafic rocks: evidence from the southern Superior Province, Canada. Contributions to Mineralogy and Petrology, 105, pp. 255-274. http://dx.doi.org/10.1007/BF00306538

Swanson, M. T. 1999. Dextral transpression at the Casco Bay restraining bend, Norumbega Fault Zone, coastal Maine. In Norumbega Fault Zone of the Northern Appalachians. Edited by A. Ludman and D.P. West, Jr. Geological Society of America Special Paper 331, pp. 85-104. http://dx.doi.org/10.1130/0-8137-2331-0.85

Thorpe, R. S. and Tindle, A. G. 1992. Petrology and petrogenesis of a Tertiary bimodal dolerite-peralkaline/ subalkaline-trachyte/rhyolite dyke association from Lundy (Bristol Channel, UK). Geological Journal, 27, pp. 101-117. http://dx.doi.org/10.1002/gj.3350270202

Trefethen, J. M. 1950. Bucksport-Orland map area. 42nd New England Intercollegiate Geological Conference Guidebook, 5 p.

Tucker, R.D., Osberg, P.H., and Berry, H.N., IV. 2001. The geology of a part of Acadia and the nature of the Acadian Orogeny across central and eastern Maine. American Journal of Science, 301, pp. 205-260. http:// dx.doi.org/10.2475/ajs.301.3.205

Wang, C. 2007. Bedrock Geology of the Fletcher Peak 7.5' Quadrangle, Maine. Maine Geological Survey, OpenFile 07-143, 16 p, scale 1:24 000 .

Wang, C. 2011. Bedrock Geology of the Great Pond 7.5' Quadrangle, Maine. Maine Geological Survey, OpenFile 12-33, 15 p, scale 1:24 000.

Wang, C. 2014. Bedrock Geology of The Horseback 7.5' Quadrangle, Maine. Maine Geological Survey, OpenFile, 24 p, scale 1:24 000.

Wang, C. and Ludman, A. 2002, Evidence for post-Acadian through Alleganian deformation in eastern Maine: multiple brittle reactivation of the Norumbega Fault Zone. Atlantic Geology. 38, pp. 35-51.

Wang, C. and Ludman, A. 2004, Deformation conditions, kinematics, and evolution of shallow crustal ductile shearing in the Norumbega Fault Zone in the Northern Appalachians, Eastern Maine. Tectonophysics, 384, pp. 129-148. http://dx.doi.org/10.1016/j.tecto.2004.03.013

West, D. P., Jr. 1999. The timing of displacements along the Norumbega Fault Zone, south-central and south-coastal Maine. In The Norumbega Fault Zone of the Northern Appalachians. Edited by A. Ludman and D.P. West, Jr. Geological Society of America Special Paper 331, pp. 167-178. 
West, D. P., Jr. and Hubbard, M. S. 1997. Progressive localization of deformation during exhumation of a major strike-slip shear zone: Norumbega Fault Zone, Maine: Tectonophysics, 273, pp. 185-201. http://dx. doi. org/10.1016/S0040-1951(96)00306-X

West, D.P., Jr. and Lux, D. R. 1993. Dating mylonitic deformation by the ${ }^{40} \mathrm{Ar} /{ }^{39} \mathrm{Ar}$ method: an example from the Norumbega Fault Zone, Maine. Earth and Planetary Science Letters, 120, pp. 221-237. http://dx.doi. org/10.1016/0012-821X(93)90241-Z

West, D. P., Jr. and Roden-Tice, M. K. 2003. Late Cretaceous reactivation of the Norumbega Fault Zone, Maine: Evidence from apatite fission track ages.

Geology, 31, pp. 649-652. http://dx.doi. org/10.1130/0091-7613(2003)031<0649:LCROTN>2.0. $\mathrm{CO} ; 2$

West, D. P., Jr., Tomascak, P. B., Coish, R. A., Yates, M. G., and Reilly, M. J. 2007. Petrogenesis of the ultrapotassic Lincoln syenite, Maine: Late Silurian-Early Devonian melting of a source region modified by subduction driven metasomatism. American Journal of Science, 307, pp. 265-310. http://dx.doi.org/10.2475/01.2007.08
Wing, L. A. 1957. An aeromagnetic and geologic reconnaissance survey of portions of Hancock and Penobscot Counties, Maine. Maine Geological Survey. no. 1, 10 p, scale 1:62 500.

Wones, D. R. 1977. Bedrock geologic map of part of the Great Pond quadrangle, Maine. U. S. Geological Survey, scale 1:24 000 .

Wones, D. R. 1980. Contribution of crystallography, mineralogy, and petrology to the geology of the Lucerne pluton, Hancock County, Maine. American Mineralogist, 65(5-6), pp. 411-437.

Wones, D. R. and Ayuso, R. A. 1993. Geologic map of the Lucerne granite, Hancock and Penobscot Counties, Maine. USGS Miscellaneous Investigations Series Map I-2360, scale 1:125 000 .

Zartman, R. E. and Gallego, M. D. 1979. USGS (D)-BUB-8 (Sample 139), USGS (D)-BUB-9 (Sample 140), USGS (D)-BUB-10 (Sample 141), and USGS (D)-ORA-301 (Sample 142). In Radiometric ages: Compilation B. Edited by R.F. Marvin and S.W. Dobson. U. S. Geological Survey: Isochron/West, no. 26, pp. 18-19.

Editorial responsibility: David P. West Jr. 